\title{
Illusions under an Alien Sky: Paul Scott's precursor to the Raj Quartet
}

\author{
Rajiva Wijesinha \\ Department of Languages \\ Sabaragamuwa University, Belihuloya
}

\begin{abstract}
Paul Scott's second novel, The Alien Sky, foreshadows the interest with the subject of Indian independence that dominates his final great achievement, The Raj Quartet. Though in this single novel Scott's obvious concern is the British reaction to independence, I believe in his presentation of his characters he also explores some of the moral concepts relating to colonialism and independence that he analyses so illuminatingly in the Quartet.
\end{abstract}

In particular he shows how elements in the individual human psyche contribute to actions and reactions within relationships based on power, which are the dominant feature of the imperial situation. One of Scott's principle themes is that, because of the power factor, even for the most idealistic of those within the system there were boundaries that could not be crossed. While Scott exposes then those who have no qualms about abusing their power, I suggest that he reserves his sharpest criticism for those who fail to live up to their expressed ideals because of their reliance on the system with which in the end they must show solidarity.

Before he began the Raj Quartet, Scott had written eight novels all of which introduce themes and characters that, with various modifications, we shall see again in the Quartet. I have looked in detail elsewhere at the manner in which Scott delivers, through the characters in the Quartet, not only a strong indictment of the failure of British commitment in India, but also a sense of what might have been achieved had commitments been adhered to ${ }^{i}$. Here I intend to look, in the novel that deals most directly with India, at precursors of themes he handled in the Quartet .

Though I believe all the other novels foreshadow Scott's final great achievement, it was his second novel, The Alien Sky, that first indicated his obsessive interest with the subject of Indian independence. Here however, even more obviously than in the Quartet, Scott's concern is the British reaction to independence, the efforts made by those who had in some sense seen India as their life to adjust to different circumstances. An important distinction however, which I shall develop later, is that the characters here have not registered the gravity of the change that has occurred, whereas in the Quartet it is the awareness of change that in different ways motivates the major protagonists.

The Alien Sky is very different from the rest of Scott's very early work, the first and third and fourth novels which are highly focused, whereas this introduces a great number of themes. They are all however connected with each other, not only in that they arise from the Indian background which here is of crucial significance, but because by and large they deal with concepts of domination and commitment or otherwise that are central to Scott's view of the Imperial experience. However, unlike in Scott's later work where different themes are 
interwoven in a manner that indicates connections between them so that the Imperial experience is coherently illuminated, The Alien Sky is a relatively disjointed work and can hardly be considered as a whole. This does not mean that it does not read very well as a novel, for a plot full of action and suspense allows it a certain forceful impact. Nevertheless, with regard to its vision as it were, all we feel is that we are presented with a number of issues that hang together only by contingence.

A catalogue of the various themes, and subjects, to use a distinction I will shortly make clear, will at its most comprehensive read as follows: the Eurasian ${ }^{\text {ii }}$ dilemma of Dorothy Gower, the sibling and other inadequacy of Joe MacKendrick, the rejected affection towards India of Tom Gower, the unsubtle exercise of and dumb adherence to authority of John Steele, Harriet Haig's bewildered concern about certain aspects of India, Milner's shamed knuckling under the new regime, Cynthia Middleton's corresponding anxiety to escape and become a memsahib elsewhere, Foster's anxiety to preserve proprieties during the changeover, the fanaticism of Vidyasagar, the bitterness of Gupta, the selfpreservative politics of Nair, the helpless acceptance by the Maharajah of Kalipur who called himself Jimmy Smith of the abandonment of the princes by the British; and perhaps even Judith Anderson's suffering because of her mixed blood, Bholu's determination to steal some money and get away to Pakistan, Dass's suffering torn between two masters, and the hotel-keeper Dessi's confusion in trying to propitiate different types of guests.

Many of these are themes or subjects we can discern elsewhere in Scott's work, but the very fact that in listing the themes in relation to a single character only we have characterized them adequately indicates how static the treatment of them here is in comparison with what we find elsewhere. In some cases certainly Scott may be making some sort of a point by this, the sort of point he enunciated in Johnnie Sahib when he referred to the essential isolation of individuals, but the point is not important or interesting enough here for us to accept readily the exclusion of the interaction that conveys so much more in his later work about the issues in question.

The catalogue can be divided into two sections, if I might make use of the terms theme and subject to distinguish between those elements that have what might be termed a general psychological dimension of the sort that plays an important part in Scott's more remarkable fiction and those that arise simply from a physical or social situation. The distinction may become clearer when we consider the case of the Eurasian Dorothy Gower, which is so vividly described that it can be considered the most important element in the book ${ }^{\mathrm{iii}}$. That judgment need not be contested, but I would suggest that Dorothy's problem is a subject rather than a theme. The diffidence under which she labours, which has made her so bitter, is something there from the start. Though her situation, her mixed blood in a hierarchical society that lays so much stress on race, evokes sympathy, it does not rouse a sense of waste: there were no illusions to be shattered there, no paradise to be lost, no one with whom feelings were shared which the situation itself destroyed.

It is clear that she loathes her husband so that, as her final conversation with MacKendrick makes clear, there is no question of her finding peace were she to confess to Tom Gower that she was of mixed blood and he were to accept her. It is conceivable that had we seen her together with Dwight MacKendrick, whom 
she had loved, to the extent even of feeling obliged to tell him her secret, we might have been more involved in her predicament. As it is, though there is more to her than to Judith Anderson in that we are brought face to face with her intense bitterness, she is not much more an object of pity than Judith who, being darker, was less strained to keep up a pretence of being white but for that very reason suffered more insults.

Indeed though Eurasians figure in a number of Scott's works, and though as his presentation of Susy Williams in Staying On shows he continued to appreciate their predicament right through to the end, his sympathy is in general coloured by amusement. Johns in Johnnie Sahib is primarily a figure of fun, and though we feel that he is unfortunate in that he cannot keep up his pretence that he comes from Buckinghamshire after a real Englishman from Buckinghamshire joins the unit, his attitude at the end even when Ghosh, his fellow Indian officer, has been killed serves to remove him from serious consideration.

In The Alien Sky, partly perhaps because it is dependent women who are involved, pity is more forcefully evoked; yet it is in a context of pity for all those who are being left behind. In the end one finds for instance Tom Gower, despite his own contribution to the situation in which he finds himself, as sad a figure as his wife. In later works when Eurasians occur they generally carry more than the weight of just their mixed blood. Anina in The Bender, though there are references to the psychological impact of her Indian upbringing and her fully Indian grandmother, is very much a part of the milieu in which she functions and it is more than likely that her assertion of her faint trace of Indian blood generally had the positive impact she anticipated from it. The more significant Teena Chang of The Chinese Love Pavilion is certainly a marvellously ambiguous figure, but though she might have been diffident by virtue of her mixed blood that is not quite clear, and in any case it is in the context of the overweening diffidence of all the men with whom she comes into contact.

Finally, as far as a central role goes, what might be termed the equivalent figure in the Raj Quartet is in fact entirely Indian: Hari Kumar is 'mixed' because his father tried to make him English, and his tragedy is not the bitterness with which as an Eurasian he might have been born but his expulsion from the paradise to which he had thought he belonged. This is much more the sort of theme that Scott thought of wider significance. The Eurasians' predicament was not in itself necessarily capable of carrying the further connotations that interested Scott, and for that reason even in its most marked manifestation in The Alien Sky it is not developed very far.

With regard to the Indians too I would argue that the same was true. Scott's predominant concern of course was the British in India, and therefore even in the Quartet itself the number of Indians who have major roles to play is small. There however, in addition to the importance of interaction, we are involved in the feelings of those who had to face up to the failure of the British to live up to their expectations, and their reactions are considered as significant. In The Alien Sky however there is no room for analysis of the reactions of Indians, and in any case those who appear are too single-minded for the probing Scott specialized in to have much point. 
So, even Nair, the least definite amongst them as it seems, is keen only to survive and prosper so that he does not really have to think twice about changing the management of the Marapore Gazette to downgrade Gower when he becomes an embarrassment. Gupta and Vidyasagar are even more obviously determined in their aims. Though the debate about the means to achieve these might have been interesting, as we can see from the reconstruction attempted by Gower, this is not placed before us so that we miss whatever conflict there might have been. This does not mean that Scott's presentation is not masterly: the intrigues we sense through Gower's account and the little bits of evidence that are noted, such as the lorry in Nair's house that might have been used to fire the farm at Ooni that Gower managed and Nair owned, provide a fascinating glimpse of those who were politically conscious in an emerging nation attempting to assert their identity. But this is a glimpse only, interesting and important enough in terms of the whole, but insufficient to allow us any deep insight into the motivations of the individuals concerned.

In any case, as suggested above, these might not have been of especial interest to Scott. The situation of the Maharajah Jimmy Smith however might at first sight have been thought to have been of greater interest to Scott, since Jimmy was in the position of having to cope with the betrayal of the British of the guarantees to the princely states on which the princes had thought they could rely. This was a theme Scott was to take up in The Birds of Paradise, and it figures to some extent too in the last book of the Quartet. Yet the reactions of the princes there, though they receive some notice, are not analyzed in detail. Once again Scott is more concerned with the attitude of the British Resident in The Birds of Paradise who tries to prevent the betrayal, and in the Quartet, where that particular Resident appears again, albeit in the background, the contrasting attitude of his deputy in Mirat who is trying to persuade the Nawab to submit. The point of course is that for Scott the moral dilemma as well as its background reflected on the British; though the reactions of the princes are to be noted, it is as subject rather than theme. Though we are made aware of Jimmy Smith's sense of betrayal, from his point of view there is nothing to be done but settle down and make the best of a bad job and that in the end is what he does.

Of more interest to Scott in this regard is the attitude of Harriet Haig, an old lady whose devotion to India might seem to foreshadow that of the various old ladies who play so large a part in the Quartet. It is significant however that the type does not recur in between and I think Harriet Haig is sufficiently distinct from the old ladies in the Quartet to make it clear that Scott has embarked upon something very different there. Harriet's social position is quite different from that of Lady Manners or Mabel Layton, whose sense of responsibility and therefore anguish at the failure of that responsibility went much deeper; and though as a teacher Harriet might have seemed closer to Edwina Crane or Barbie Batchelor, they were missionaries who were able to sense an obligation towards the 'unknown Indian' and were aware, dedicated as they might have been to their duty, of their own insignificance. Harriet on the contrary had been governess to a Maharajah, and saw herself as having contributed considerably to his ability to rule -

Jimmy was a good boy. One had seen how good, one had seen the goodness expressed in the changing lives of the people he ruled; for there had been so many things which had made one's heart ache in his father's day: poverty and squalor and wretchedness contrasting so strongly with royal luxury. Had one been too militant? Had one influenced the boy too much to see the barrier which separated the ruler 
and the ruled, influenced him too strongly - (was that the reason for so much Dickens?) - to try to break it, to lead his people into a new life of self-respect? "Was that well done, Harriet?" Oh yes, it was! It had been, and one rejoiced to know one could work creatively through others. ( $p$ $35)^{\text {iv }}$

Salutary as the effect of Harriet's efforts might have been, her approach contrasts quite forcefully with the sort of inspiration Scott was later to describe with regard to Edwina Crane in The Jewel in the Crown - 'And it came to Miss Crane then that the only excuse she or anyone of her kind had to be there, alone, sitting on a chair, holding a nosegay, being sung to, the object of the awe of uninstructed children, was if they sat there conscious of a duty to promote the cause of human dignity and happiness' (p 15-6). ${ }^{v}$

In both cases the ultimate aims may be good ones, but in Harriet there is an obtrusive element of self-fulfillment in the task. The consequence, and this might almost stand for a metaphor of the whole Imperial process in India as it worked out, admirable though some of its aims might have been, was that when a difficulty occurred it was her own aspirations that took precedence. When Jimmy Smith comes to Marapore she does not think that he would want to see her since there is nothing she can do in a situation in which 'the States had been deserted and left as vulnerable islands to be eaten away by hungry seas' ( $p$ 36). Yet though she is right, and she realizes this inasmuch as he has not informed her that he is coming, as soon as she finds out about the visit she rushes to see him and then, when he brings up the subject of Tom Gower, she pounces eagerly on his suggestion that he might offer Gower a job. She then has a dinner party so that the offer might be made, and busies herself about the business without taking into consideration the actual situation wherein Jimmy's imminent trip to Delhi might prove that he is powerless to offer anyone anything.

This indeed is what happens, but Harriet continues to do her best for Tom. The observation Scott makes through Jimmy, that Harriet's interest in Gower is based on the fact that he reminds her of someone she was in love with many years ago, makes clear to us that Harriet's aims and aspirations are still basically British and cannot take into consideration the reality as it affects Indians. This does not prevent her from having accomplished some good, but she is certainly incapable of the commitment and the consequent moral anguish that characterizes the women we see in the Quartet. She was doubtless a more common specimen at the time, and the manner in which Scott establishes her limitations, her sensitivity to sufferings she can comprehend together with her blindness to what was not British and therefore beyond her, illuminates vividly I think an important aspect of the Imperial attitude. ${ }^{\mathrm{vi}}$

Harriet Haig then is still a memsahib, albeit a good one; the portrayal is unusual enough to be thematically more interesting than that of the conventional memsahib Cynthia Middleton. This latter however is vividly enough sketched to provide, together with the counterbalancing depiction of Major Milner, an interesting sidelight on some reactions to the conclusion of the Imperial relationship. Milner had been used to commanding, and Cynthia to being waited upon, and though neither had had prominent enough a role to build up any extravagant image of themselves both realized that they would never be content back in Britain. Milner decides to stay on in the belief that the Indians would " go 
on their knees for any of us that'll stay on" (p 16) and has a rude shock when an Indian is put in command over him at the depot. Cynthia Middleton on the other hand decides to go to Kenya; in pursuing a man who has no obligations to her and in having to manoeuvre money out of strangers to survive, it is clear she needs other means to continue to assert herself. The implication is that the negative aspects of the position she needs to cling to, the veiled suggestions of her superiority to Jimmy and the open victimization of Judith Anderson that she indulges in, will not be so readily available to her after the general exodus of the British.

Such vulnerability in the British at their departure from India will not be seen again in Scott. In Staying On time has passed so that, though the sense of sustained loss may in the end be more powerful, the immediate trauma of having to find a new role is not apparent. Conversely the characters in the Quartet, presented over a longer period of time, have more resources to face what given their positions might be a greater loss, but not one that presents immediate practical problems. In The Alien Sky on the other hand, neither Milner nor Cynthia appears to have been to any appreciable extent emotionally involved in the Imperial process, and the problems we see are therefore clearly situational rather than psychological. However the adjustments they have to make are difficult enough for us to feel some sympathy, and also to appreciate the rather unfortunate position they occupy in the hierarchy as well as the irony of Milner's original reflections on the change -

Swank and snobbery had done for the whites in India. He shut his eyes, Swank and snobbery. If you weren't out of the top bloody drawer, you'd had it. Now it was a new era. The era of men with a bit of common sense. He opened his eyes again and the greenness and the sunlight and the heat embraced him with arms within whose circle he was infinitely content. ( $p$ 17)

Emotionally, it turns out to be Tom Gower who suffers the most because of the independence of India. At first glance this seems paradoxical, for it was a land he loved and a land it seemed he was prepared to love on its own terms; unlike the other British characters, he abhorred 'the wrong outlook, the outlook of the Burra Sahib, believing in his own omnipotence; this possessiveness, this feudalism, this benevolent despotism which passed for racial understanding.' ( $p$ 82) Yet it is clear that this is not enough to make him loved by the Indians, and he is forced into giving up both the editorship of the Marapore Gazette and his experimental farm at Ooni. The explanation for all this is not in fact difficult to comprehend, and has indeed been given to us very early in the novel by the politically aggressive Gupta, as he talks to the American MacKendrick -

"Tom Gower is a name not unknown, you see. He is in India many years and takes our problems to his heart... But, Mr. MacKendrick, they are our problems, but his heart is not our heart. A solution to the problems of one is not found in the heart of another but in one's own. We cannot accept his solutions to our problems... When he tells people of his own race how they should comport themselves in our country, we applaud him. But when, for some reason, he begins to tell us how we should comport ourselves, what we should do, what we should think, what solutions to our problems we should find -"

"You insult him?"

Gupta sighed. "Our modern young men are less restrained than we who have been schooled to listen quietly to well-meant advice." ( $p$ 45-6) 
We can see then in Tom Gower a resemblance to Harriet Haig, with regard to the elements noted above. As with Harriet, the character of Gower was not one that Scott repeated. The reason I think is that those with whom he was primarily concerned in his Indian work were either those who tried to preserve their status within an Imperial relationship or those who rejected that status for moral or other reasons to mark their actual involvement with the country. Gower on the other hand tried to preserve his exalted status within a relationship that was no longer an Imperial one. Though with good intentions, he continues like Harriet still to patronize. It is not I think entirely to provide a reason for Gupta's bitterness that Scott establishes that he had been editor of the Gazette before Gower. We are aware that Gupta is in any case a bitter man, and we can see that political reasons are as important to him as personal ones for wanting Gower out of the editor's chair. Rather, the fact that Gower intrinsically finds it impossible to work under Gupta as Managing Editor, without attempting to understand Nair's position, underlines the fact that he had been quite content to deprive Gupta of a job and thereby doubtless alter the editorial policy of the Gazette, but is unable to take direction himself. In short he still functions in a world in which he is a privileged person.

It is because he still thinks of himself as privileged that Gower is insensitive enough almost to welcome the creation of Pakistan ${ }^{\text {viii }}$ and to support Jimmy Smith's intention that Kalipur should remain independent. Using Jimmy Smith, Scott advances the suggestion that it was the very fact of partition that created a dilemma for the princes -

"The Mountbatten plan leaves the Princely States in the lurch, my dear. He hadn't any other choice, of course, but the lurch is the lurch. Half my subjects are Muslims and half are Hindus. I am a Hindu. I have three alternatives. I can become a part of Pakistan and then from the religious point of view half my subjects will be aliens with the right to become refugees. I can cede to India. The same applies in reverse. The third alternative is for me to declare my independence. I can become a sovereign state. It is an interesting thought, don't you agree?" (p 59)

The general impression, one that had been encouraged by a number of British Residents at the princely states, as in the example Scott furnishes in The Birds of Paradise, was that the diehards amongst the British were encouraging the states to be recalcitrant in line with the original reluctance to grant independence. In such a context, Gower could scarcely have underestimated the inflammatory effect of the editorial he wrote. The point of course is that he did not need to: if there were trouble, he could always go back to England, as indeed he tells his wife - "Well, if I am finished, Dor, we'll pack up and go home." ( $p$ 73). If he cannot continue in control in India, he can always get away; and when to his astonishment his wife refuses to go back to England, he aims for a retreat to an independent princely state, the final acknowledgment that despite his love for the land he cannot really think in terms of an independent India at all.

Once what might be called this preciousness in Gower is registered, we can appreciate better other aspects of his character that Scott introduces. There is for instance his burning jealousy of his assistant Steele. He thinks his wife must be having an affair with Steele, for he cannot conceive of any other reason why she should be unwilling to go to England, and he thereupon attempts to characterize 
Steele in a manner that establishes his own superiority. This is most obvious in his view of Steele as a man of violence, ready to assert himself by virtue of the weapons he carries. Gower sees this as a form of cowardice, for he thinks Steele would not be so ready to assert himself if he did not have the weapon, and he also thinks Steele's notion of being prepared is in itself dangerous and begets violence in that the very carrying of the weapon encourages its use and that of others in response. This last seems to be true in that Steele unnecessarily shoots MacKendrick's servant Bholu who, far from coming to attack him, is simply fleeing a mob that is pursuing him, and not entirely seriously at that. Yet at the moment of what had seemed a threat Gower himself had remained silent and allowed Steele to act, while earlier he had stopped Steele from taking precautions or reconnoitering. It could therefore just as easily be said that it was the combination of the two attitudes that caused the tragedy. ${ }^{\text {ix }}$ Certainly later Steele seems to prove to Gower that he is no coward, when he leaps unarmed, unsuccessfully, at Vidyasagar as he is shooting him. The irony is that by this point we have realized that it is Gower who acted as he chose because he thought himself secure in the protection of his privileged position. When at the end he tries to commit suicide because the job with Jimmy has fallen through and his wife has left him, we realize how very much he needs protection in that underneath he has nothing substantial to which to hold on.

Symptomatic of his underlying diffidence is the ambiguity Scott makes clear in his attitude to Indians, that underlying the liberalism there was a sense of revulsion at the idea of ordinary contact. When after Steele's funeral he comes across the girl who is bearing Steele's child, he cannot bear the thought of any claim -

He had only to bend down and touch her shoulder. He had only to do this simple, almost undemonstrative act, to prove his understanding and his compassion. But his arm was fixed rigidly by his side. Where there should have been compassion there was only distaste, and where there should have been understanding was only the desire to turn away... Knowledge of the child stunned him. The child was obscene, sprung from an act of lust and the urgency of the flesh's need. The child was not Steele's, nor was it the girl's. Rather it seemed a growth, a canker, from which both would have turned in disgust, back to the inviolacy of their separate spirits. (p. 187)

Though as was pointed out earlier, Dorothy's confession of her mixed blood would not have helped her much even if her husband had accepted it, it is apparent now that the easy assumption a cursory reading of the book might have provided, that it would have made no difference to him, would not have been accurate. Despite his liberalism, Gower clearly fails one of the tests we shall later see applied in the Quartet, the acceptance of miscegenation. ${ }^{x}$

Yet that is only half the story. Alongside the revulsion in this context we are aware that there is in Gower an urge to establish himself in this land, to make some sort of an impact on its inhabitants. At the same time we have noted in him what might be called a streak of passive cruelty, or perhaps prurience, in that despite his detailed analysis of what was going on amongst the Indians that led to the outburst at Ooni, despite his characterization of Steele as 'the man who brought the tight spot with him' ( $p$ 156), he takes no steps himself but allows things to run their course. At that point the focus of his interest was Steele and, though of course he would not have willed the tragedy, from the vigour of his reprimands we should have realized even perhaps had Scott not stated it that 'he wanted Steele to suffer; suffer in the way he himself was suffering; feel driven 
into a corner; feel those first, exploratory tentacles of fear.' ( $p$ 135) These strands come together even more significantly in the scene in which, after Steele has been shot, Gower insists on seeing Vidyasagar in prison: Scott's account emphasizes an element which might otherwise have escaped us -

And now they were together Gower knew the real reason why he had come. He wanted to see the boy cower. He wanted the boy to fall on his knees and cry and beg for mercy. And he wanted to beat his own hands on the bars, beat and beat until the skin was broken and the blood came and some of his own agony was released to enter into the boy. Hoarsely, he said, "I came to see if there's anything I can do for you." ( $p$ 188)

We recognize now that Gower's constant awareness of Vidyasagar previously arose from a more than ordinary interest in him; and we understand more fully now an earlier reference, when Gower was explaining the incidents of violence to Steele and the District Magistrate Foster, to his registering of how he had once before reacted to Vidyasagar - 'Then he remembered Vidyasagar's eyes, that day on the maidan. Was it through Vidyasagar's eyes he had first seen the flesh and the spirit yielding to corruption: his own flesh, his own spirit?' (p. 175)

There seems to me little doubt that this assertion of the possibility of personal inadequacy suggests homosexuality or sadomasochism or both, the scene in the prison providing confirmation of this, anticipating as it does the more famous scene between Merrick and Hari Kumar in The Day of the Scorpion. Characteristically Scott provides us with another clue to drive in the point, exemplifying him at his allusive best: preceding Gower to see Vidyasagar was the homosexual school principal Sanderson who had been, gratuitously one might almost have thought then, characterized by MacKendrick when they first met as a 'fairy'. Scott does not develop the point, in concordance doubtless with Gower's inclinations: Gower was never likely to work out his fantasies as Merrick did; but we should surely recognize the possible consequence of the urge for a closer relationship, that would still preserve his dominant status, on the part of even a keen liberal precluded from or diffident about other forms of contact. ${ }^{\text {xi }}$

Balancing Gower is his appropriately named assistant John Steele. Like Johnnie Brown who had, matching his name, a 'compact little body' (Johnny Sahib 142), which indeed recalls those of Forster's sturdy young men, Steele's 'skin was burned copper, and while he was not above medium height, his body and limbs were thick and sturdy' ( $\mathrm{p} \mathrm{86-7);} \mathrm{he} \mathrm{foreshadows} \mathrm{too} \mathrm{Alan} \mathrm{Hurst} \mathrm{in} \mathrm{A} \mathrm{Male} \mathrm{Child,}$ who refers to Steele's work at Ooni with regret that he did not himself stay on in India, and again Tom Brent in The Chinese Love Pavilion who, while he was working with Greystone on an experimental agricultural station like that at Ooni, in the sort of valley to which at the end of the book he returns, 'had taken to wearing nothing but an old pair of shorts during the day and the sun had burned my skin to the colour of copper' (Chinese Love Pavilion p 43).

Unlike Forster's young men however, who are generally subordinate and conscious from the beginning of disadvantages that have a social origin, Scott's are recognizably protagonists from the start and are comparatively more assured. At the same time, as the novels develop, this becomes more and more qualified, and in any case all of them face some sort of bewilderment in the course of their stories. Johnnie, as we have seen, was able to recover. Steele, 
just a couple of years later but in a totally different environment where his authority was no longer assured, is killed.

Scott's description of the change he undergoes is swift and succinct. When we first meet Steele he has, as he thinks, just settled the strike at Ooni by firm persuasion. He does not think he stepped beyond proper limits, but Gower's questioning suggests the possibility of a different perception of the situation -

Gower said, "How - persuade?"

"I threatened 'em."

"Not physically, I hope."

Steele looked thoughtful. "I know it's wrong," he said at last, "and anyway I didn't actually do it like that. At least-... l'd've liked to've hit him I admit, but I'm not such a fool. Perhaps I made some sort of movement. I don't know. I felt like knocking his teeth back but I didn't. I didn't even look aggressive. I mean-"

"More than you could help?"

"You know what I mean. We were alone of course and I expect he thought he was in for a bashing. But I honestly didn't do a thing except want to bash him. Anyway it had the right effect." ( $p 88$ )

Later, when Dass is beaten by those who are angry that he gave in, and then the marks give rise to the rumour that it was Steele who had beaten him to make him call off the strike, Steele is horrified. Yet at the end he understands that the limits he had observed, the rules of conduct he had set himself, were meaningless to those at the other end: when he thinks of leaving Ooni, but going somewhere else in India, back to the life he loved, he realizes using a metaphor taken up from Gower that the situation has now changed - 'And wherever he went in India, would always be the heat, the blessed sun, the merging of days that wasn't like time passing, or anything to do with time... But now behind these thoughts, always that other thought waiting to pounce. Before, you always had a gun.' ( $p$ $182)^{\mathrm{xi}}$

No longer can his actions spring from a secure conviction of his own inviolability. $\mathrm{He}$ is now in a world where the local girl with whom he had been living for eighteen months, whom his bearer had procured for him as he had done before during the war, has become, in Gupta's words, "a Hindu girl... brought to him by a Muslim... Some say this Hindu girl was abducted" (p 124). Again, after he has killed Bholu, though the servants still fix 'their loyalty on the young man with the gun at his waist, as though loyalty came first, understanding after', it is now to alter the evidence, insignificantly enough in itself perhaps, but significantly because it arises from Steele's lack of confidence, his uncharacteristic involvement in an 'intrigue... that had wrapped itself round Steele's common sense' ( $p$ 168). Most tellingly, when Steele is persuaded that he should face an inquest over the killing since it would be in his interests to expunge the taint that it is asserted hangs over him because of all his actions, he is aware of a shift in values that had brought down everything on which he had hitherto relied -

"All this Muttra Dass nonsense and the business about the girl you live with. Now this Bholu affair. Feeling is pretty high against you, y'know. Better clear the air and make it official that no blame attaches to you concerning his death. The Indians'll love it"... At any other time the things Foster had said would have persuaded him of the rightness of the decisions made. He would have seen them as appeals to reason and 
appeals to justice; appeals to the code long since adopted by himself. This morning the code did not work. One by one, he felt, his gods were falling, and he dimly knew, and sharply felt, that he, John Steele, was being exploited ( $\mathrm{p}$ 171-3)

Yet though we feel sorry for Steele, the point is that the code had hitherto worked at two levels. The sort of death Bholu died should have been the subject of an inquest at any time, not only under special circumstances. Whatever restraint Steele had felt himself exercising previously had been the restraint of a dominant power. He had been accustomed to authority that both guided and justified, and he had never thought to question its impact on those who had no claims under it. In its own way therefore his awakening is as traumatic as that of Gower and, though he might be basically decent and straightforward, given the different circumstances he might have found it even more difficult to adjust. His death then, imposed by Vidyasagar, parallels the suicide that Gower attempts upon himself.

Finally, with the American Joe MacKendrick, we are introduced to what Swinden describes as 'a subject that was absent from Johnnie Sahib, but which is to play a very large part in the later novels: the perverse, often sadistic relationship which can develop between elder and younger brothers.' (Swinden, 21) As can be understood from Scott's next novel, A Male Child, the fraternal relationship itself is not that important, and Swinden himself grants this when he refers to the absence of a blood-relationship in what he describes as 'the most deeply explored example - Ronald Merrick's relationship with Hari Kumar in the Raj Quartet'. Rather I think Scott's presentation of Joe is more important in terms of its thematic significance, which relates to Scott's primary concern with the Imperial relationship. In this respect I would argue MacKendrick has closer affinities with other characters rather than the 'younger brothers' Alan Hurst or Bob Ramsay or Hari Kumar; and closest of all, as Scott himself suggests, with Tom Gower in the very same novel.

The importance of Joe's brother Dwight lies in what he has contributed to the character of Joe as it is exposed before us. Joe comes to Marapore initially in pursuit of Dorothy Gower because he has discovered from the dead Dwight's letters that they had had an affair but that, despite the urgency of her love, Dwight had abandoned her. This moves Joe because it seems typical of the brother who had bullied him, who had been set up for him as a standard, but whose values he deplored; or perhaps whom he hated simply because he could not keep up with him. Joe is aware of both these possibilities so that, though his primary motive in coming to Marapore is to recompense Dorothy by offering himself as a substitute for Dwight, he is aware also of his need to prove to himself that he can do what Dwight did. There is about him throughout an air of anxious sexuality, as when he thinks of Gower at their first meeting as the man he had, in his heart, already cuckolded' ( $p 53$ ), or in his dealings with Cynthia Mapleton, to whom he gives money, whereupon

they both wondered whether he had purchased the right to sleep with her. They treated one another with a wary respect... He knew that to possess her would be for him at once an act of revenge and an act of surrender; revenge for what had been withheld, surrender to what he had tried to escape. An affair with Cynthia Mapleton would bear the hall- 
mark of his family: no risk, a sure thing. And, of course, he had paid for it already.

(p.98-101)

All this however comes to nothing, and it becomes clear, at the end in the scene in which his attempt to go away with Dorothy fails conclusively, that Dwight had been as much an

excuse for him as an inspiration (my stress) -

She stood up and he was so close to her, so challenged by her anger and his sense of shame that he gripped her shoulders and pressed his mouth on to hers, not in physical passion but in a desperate attempt to show he was not afraid of her or of himself, to show that he could make a decision, take control, smash down opposition. But as he was about to push her away she suddenly arched her body, pressing her thighs against his, shooting her tongue up and into his mouth, pressing her hands into his back. For an instant his body responded and, with urgency, he lowered her on to the bed, to go through preliminaries of an act of union, but as he did so, the urgency dissolved into the slow humiliation of impotence. He took her head between his hands and tried to recapture the moment of fever. But the fever had been in his mind, not in his blood... He was repelled by the physical hunger he had awakened in her. He felt her body relax and go taut with scorn... He said, with the inspiration of stricken pride, "You were thinking of Dwight. That's why it wasn't any use. You'd always be thinking of Dwight. It'd never be me. It'd never be any use." (p. 205)

Dorothy's awareness of his inadequacy is clear from her last words as she leaves him -

"Just keep on telling yourself I'd always have been thinking of Dwight or that l've always got to have someone to hate so that I don't hate myself. If that doesn't work then keep on telling yourself I can't be judged like an ordinary person by ordinary standards. Keep on reminding yourself that I'm a freak, like something in a sideshow."

When she closed the door and left him alone the formula was already beginning to work.

And so finally, in one of those telling codas with which Scott ties up his novels, MacKendrick goes to one of the dancehalls where the Eurasian girls gather, looks inside, and then leaves without entering: as always.

Though in a novel that packs so much into so short a compass the character is not thoroughly developed, and though it takes careful attention to grasp its significance, MacKendrick's relevance to Scott's fundamental concerns cannot, I think, be gainsaid. At its broadest, his original purpose in appearing in Marapore, to replace the dead Dwight, has its historical parallels, as early on in the book Cynthia Middleton reminds us - "'The British are going and now it's your turn. Whether you like it or not, all they're doing here is exchanging the Union Jack for the dollar sign." ( $p$ 24). Related to this is the difference between Dwight's methods and what could be thought of as a new dispensation, though not necessarily - "Dwight streamlined himself for success and cut his way through anything and anybody... We'd all be like Dwight if we knew how, but because we don't we cook up a lot of hooey about truth and honour and decency and fair-play when all the time the only thing that adds up is our own goddam selfishness" ( $p$ 79). Most importantly, MacKendrick diagnoses another similarity, that can be 
seen as underlying the hollowness of his ideals of which he is aware - 'It was easy for him to see the likeness between Gower and himself. Both their skins bore the smell, the taint of defeat' ( $p$ 73). My argument therefore is that we have to see MacKendrick too as symbolizing an aspect of Imperialism, exemplifying a diffidence due to deprivation elsewhere and for that reason doubtless needing to overcompensate in its hunger for possession; in spite of its rationalizations and justifications still determined to dominate; because of them driven to compulsiveness and artificiality.

Later, in The Corrida at San Feliu, Scott has his narrator Thornhill (who has many similarities to Gower) claim through one of his creations, "There is no love without compassion, no compassion without self-pity and no self-pity that hasn't sprung from deprivation and a terrible lust for possessio" ( $p$ 145). My view is that, some years before it was examined in that novel, The Alien Sky had already suggested the inadequacy of that sort of love. Though he is seeking his own fulfillment through Dorothy, MacKendrick's inbuilt diffidence holds him back. One might indeed argue that the conclusion of their relationship suggests that Dorothy represents not merely the deprived Eurasians, but India itself, which can be loved while the notion of patronage lasts, but which cannot be endured when it reveals its own 'terrible lust for possession'.

In effect, what all the various attitudes that proliferate in The Alien Sky have in common is that they do not permit, indeed cannot cope with, reciprocation. At the level at which it would be otiose to attribute guilt, Steele is bewildered when he is asked to subscribe to a new code where he is not the obvious beneficiary of loyalty without understanding but is instead himself to be exploited without understanding. More seriously, Gower, who realized that "All we understand is that individual kindness isn't enough. But perhaps our strength lies in the fact that we don't understand what is enough. Perhaps we don't want to understand." ( $p$ 142 ), tries after Dorothy leaves to kill himself, having achieved a terrible recognition -

And then his cry died away and his hands fell, for he understood, quite suddenly, that they were each a reflection of the other.

She saw that he had understood, at last, and nodded.

"Yes," she said, "It's your turn now." (p 197)

The message Gower leaves behind him is the Biblical verse 'Jesus wept'; this is followed, as he may have noticed in rereading it before attempting to cut his wrists, by the lines 'Then said the Jews, Behold how he loved him'; Gower's tragedy, though he survives, is that there is no possibility of resurrection for the relationships he had imagined he could inspire, but which the ambiguities in his own character preclude him from achieving in himself.

My argument then is that The Alien Sky is a very ambitious work, and full of substance relating to Scott's major concerns. It is not a wholly successful novel because there is too much bundled up together, and the various strands are not strung together tightly enough to give a totally clear view of Scott's account of the Imperial relation. Yet there is a lot here that illuminates that relation; and though, as I have mentioned, the sort of single dimensional character he examines here is not for the most part repeated, the publication of this book thirteen years before the first volume of the Quartet indicates that Scott's ruthless analysis of that relation, and the inevitability of its failure because of diffidence and the 

start.

'See 'Travesties: Romance and Reality in the Raj Quartet', in the Journal of Comparative Literature and Aesthetics, Orissa 1998, 'Sex and the Single Girl: Scott's recommendations for the Raj', in 'Gladly wolde she teche and lerne': Essays in honour of Yasmine Gooneratne, London 1999, 'The Hollow Men: Paul Scott and the end of empire' in Fact and Fable: Aspects of East-West Interaction, Sabaragamuwa University Press, 2000 and 'A deeper communion: the older women of The Raj Quartet' in the Rhodopi publication of the proceedings of the 2000 Tubingen EACLALS Conference.

ii I use this term here rather than the now more favoured 'Anglo-Indian', justifiably I believe given the period and the work with which this essay deals. As Loretta Mijares clarifies, in her illuminating essay "You are an Anglo-Indian?": Eurasians and Hybridity and Cosmopolitanism in Salman Rushdie's Midnight's Children' (JCL 38: 2, 2003), there is a clear distinction 'with "Eurasian" generally signifying the construction of mixed-race characters in colonial and postcolonial fiction, and "Anglo-Indian" indicating a more formal association with a self-identified "community"'. The people Scott was concerned with would not of course have sought such identification.

iii This in itself is unusual in Scott's early work. As Patrick Swinden puts it in Paul Scott: Images of India, Macmillan, London 1980, p. 7, in talking about this novel, 'Dorothy Gower is the only female character in the pre-Quartet novels to be given as important a role to play as any of the men. Her situation is an interesting one, and her character is explored with some subtlety - as I shall try to show but in the end Scott doesn't manage to give as clear a picture of her as he does, say, of Johnnie Brown or... Certainly there is little in the earlier novels to prepare us for the startlingly penetrating and varied presentation of the female characters in the Quartet'.

Though, as Swinden grants, there is much more to be said about Scott than his own early study was able to develop, his book was for a long time the best introduction to Scott's writing. The other early fulllength study in English was that of K. Bhaskara Rao, Paul Scott, Twayne Publishers, Boston 1980 which, though making a few interesting points, contains a number of factual inaccuracies. Fortunately, Francine Weinbaum's Paul Scott: A Critical Study, Austin 1992, has provided a more reliable analysis. iv Quotations from Scott's work will be only by page number, except when the particular book cited may not be clear. Page references with regard to the early novels will be to the Granada Panther edition, while references to the Quartet will be to the Heinemann collected edition.

$\checkmark$ I am reminded of one of the most positive declarations I ever heard, that there was no point in having protégés unless they ended up better than oneself. The general incapacity to appreciate this I think lies at the heart of Scott's attack on British India.

${ }^{v i}$ Francine Weinbaum perceptively notes, in Paul Scott: A Critical Study, Austin 1992, that 'Scott is at pains to show through the views of characters we like and admire that it was not love of India that motivated a nation that prided itself on its principles so much as a concern with retaining its self-image' (p 106).

vii Antony Copley, in 'The Politics of Illusion: Paul Scott's The Raj Quartet' (Indo-British Review: A Journal of History, $\mathrm{XI}: 1$ ) points out what clearly applies to Cynthia Middleton too, that 'protectiveness and dependency drove the memsahibs into an artificial situation, thwarting a more natural life-style: this driving them inwards does much to explain those cruelties of petty ambition, class snobbery and racial animosity' (p 69).

viii I have argued in 'A deeper communion...' (Rhodopi) that Scott shares the belief of Lady Manners in the Quartet that 'The creation of Pakistan is our crowning failure... Our only justification for two hundred years of power was unification. But we've divided one composite nation into two' (The Jewel in the Crown p 444).

${ }^{1 x}$ We see a similar thing happen in The Chinese Love Pavilion, while the massacres in Mayapore in The Jewel in the Crown might have been exacerbated (The Day of the Scorpion p. 77) by the Deputy Commissioner White's distrust of Brigadier Reid and his attempt to delay calling out the forces until he was forced to do so by his Commissioner's orders. What happens in all these cases perhaps reflects Scott's view of the actual balance of strength between conciliatory and aggressors amongst the British in India: the guns were always present and generally used before anything else had had time to work, because of a combination of distrust and arrogance.

${ }^{x}$ Max Beloff's realization, in 'The End of the Raj: Paul Scott's novels as History' in Encounter 46: 5 that the Quartet conveyed 'the full tragic significance of the combination between a sense of duty and a sense of permanent alienation from those to whom the duty was owed' may not be irrelevant here too.

${ }^{x i}$ Ralph Crane, in 'Playing the White Man: Ronald Merrick, Whiteness, and Erotic Triangles in Paul Scott's The Raj Quartet' (JCL 39: 1, 2004) draws attention to the concept of 'asymmetrical erotic triangles - that is triangles which take into account the power differences that are introduced through the race, class and gender of the participants, which explore, in other words, the asymmetries of power integral to the colonial framework' ( p 20). Though the triangles he explores deal with 'homosocial desire' expressed through the mediation of a girl as well, this early example of an all male triangle, with the strange suggestion of corruption, suggests Scott's understanding of the different forms attraction could take in the context of power differences.

xii Benita Parry touches on one reason for the bewilderment that overtakes people like Steele when circumstances change when she notes, in 'Paul Scott's Raj' (South Asia Review, 8:4, July/October) 'the 
ultimately destructive psychological satisfactions of having power over subjugated peoples, which enslave the masters and paralyse their capacity for choice and the exercise of free will' ( $p$ 366).

\section{References}

Beloff, Max. 1976. The End of the Raj: Paul Scott's novels as History. Encounter 46 No 5.

Childs, Peter. 1998. Paul Scott's Raj Quartet: History and Division. English Literary Studies, University of Victoria.

Copley, Antony. 1984. The Politics of Illusion; Paul Scott's The Raj Quartet'.IndoBritish Review: a Journal of History XI No 1.

Crane, Ralph. 2004. Playing the White Man: Ronald Merrick, Whiteness, and Erotic Triangles in Paul Scott's The Raj Quartet. Journal of Commonwealth Literature 39: 1.

Mijares, Loretta. 2003. "You are an Anglo-Indian?": Eurasians and Hybridity and Cosmopolitanism in Salman Rushdie's Midnight's Children'. Journal of Commonwealth Literature 38: 2.

Parry, Benita. 1975. Paul Scott's Raj. South Asia Review (formerly Asian Review), Vol. 8 No 4.

Scott, Paul.1953. The Alien Sky, London : Eyre \& Spottiswoode.

Scott, Paul. 1960. The Chinese Love Pavilion, London : Eyre \& Spottiswoode.

Scott, Paul.1964. The Corrida at San Feliu, London : Secker \& Warburg.

Scott, Paul. 1977. The Jewel in the Crown, London: Panther.

Scott, Paul. 1977. The Day of the Scorpion, London : Panther.

Scott, Paul. 1986. My Appointment with the Muse: Essays 1961-67, Shelley C Reese(ed.) London : Heinemann.

Swinden, Patrick. 1980. Paul Scott: Images of India, London : Macmillan

Weinbaum, Francine, S. 1992. Paul Scott: A Critical Study, Texas: University of Texas Press. 